\title{
PERAN HKBP SIHORBO TANJUNG DALAM PENYEBARAN AGAMA KRISTEN PROTESTAN DI DESA RURA TANJUNG, KECAMATAN PAKKAT, KABUPATEN HUMBANG HASUNDUTAN, 1956-2018
}

\author{
Monika Sipahutar*, Ahmad Fakhri Hutauruk, Asnewastri \\ Program Studi Pendidikan Sejarah, Universitas Simalungun, Sumatera Utara, Indonesia
}

\begin{tabular}{|c|c|}
\hline Article History & \multirow{6}{*}{$\begin{array}{l}\text { Setelah dilakukannya zending RMG ke wilayah Nusantara, maka tak } \\
\text { luput pula RMG masuk ke Tanah Batak. Diawali dengan berdirinya gereja } \\
\text { di Tarutung hingga meluas ke seluruh wilayah Tanah Batak. Zendeling } \\
\text { Pekabaran Injil Zending Batak yang pertama sekali diutus oleh Zending } \\
\text { HKBP ke Desa Rura Tanjung adalah Gr Ogus Hutagalung sejak tahun } \\
\text { 1920. Gr Ogus Hutagalung berhasil menyebarkan agama Kristen } \\
\text { Protestan terutama kepada penduduk yang belum menganut agama. } \\
\text { Penelitian ini menggunakan metode penelitian sejarah. Adapun hasil } \\
\text { penelitian yang diperoleh bahwa berdirinya HKBP Sihorbo Tanjung tidak } \\
\text { terlepas dari pengaruh pengembangan Zending atau Pekabaran Injil ke } \\
\text { berbagai daerah sebagi indikator panggilan gereja yang hidup seperti } \\
\text { Zending Batak yang datang ke Rura Tanjung. Peranan HKBP Sihorbo } \\
\text { Tanjung dalam menyebarkan agama Kristen Protestan di Rura Tanjung } \\
\text { semakin berkembang hingga sampai sekarang (2018) terlihat dari } \\
\text { berbagai bidang misalnya: bidang pendidikan, bidang Diakoni } \\
\text { (pelayanan sosial), bidang kesehatan, bidang ekonomi. }\end{array}$} \\
\hline Received : Sept 20, 2019 & \\
\hline Accepted : Sept 24, 2019 & \\
\hline Published : Sept 24, 2019 & \\
\hline Kata Kunci & \\
\hline $\begin{array}{l}\text { HKBP, Sihorbo Tanjung, } \\
\text { Kristen Protestan, Humbang } \\
\text { Hasundutan. }\end{array}$ & \\
\hline
\end{tabular}

\section{PENDAHULUAN}

Sejak awal, banyak orang yang menganggap bahwa kelahiran Pietisme adalah sebagai gerakan sektarian yang berusaha memisahkan diri dari Gereja sebagai institusi. Ada tuduhan yang bermacam-macam. Ada yang mengatakan bahwa Pietisme itu lahir dari berbagai kelompok yang memisahkan diri dari Gereja yang sah, seperti sekte Pelagian, Socianian, Quakerish, dan dari sekte Armenian. Akibat dari praduga ini, banyak teolog maupun Gereja resmi menolak kehadiran Pietisme dengan berbagai alasan. Ada yang menolak aktivitas Pietisme karena alasan doktrin mistik yang di kandungnya, di mana ada kesan doktrinal yang mempersekutukan Allah dengan manusia.

Lahirnya Pietisme adalah menerapkan reaksi koreklis terhadap kemampuan gereja diperoleh pada abad ke-17. Reformasi Martin Luther pada akhirnya ternyata tidak cukup lama menghidupi spritualitas Reformasi Gereja pada waktu itu. Pada akhirnya Reformasi Martin Luther tersebut kandas dengan kemapanan dan stagnasi spritualitas kehidupan Gereja pada waktu itu. Untungnya, dalam penghujung reformasi itu masih terus berkumandang slogan dan pernyataan teologis reformis: ecclesia reformata simper reformanda (gereja yang sudah diperbaharui itu masih terus dan akan diperbaharui lagi) (Lumbantobing, 2018: 173).

Gerakan Pietisme lahir atas keberadaan dan kehidupan spritualitas yang terjadi di dalam Gereja. Pokok persoalan yang dihadapi adalah kehidupan spritualitas warga 
jemaat yang stagnan, kaku, dan tidak bergairah. Itu berarti reformasi teologi dan dogma tidak cukup membangunkan kehidupan spritualitas. Harus ada pendorong melalui tindakan dan aksi serta praktek hidup. Penghayatan dan pemahaman tentang teologi dan firman Tuhan harus dilakukan di dalam tindak laku yang nyata dan konkrit sebagai realitas makana kebenaran, kebaikan, dan kekudusan atau kesalehan. Konsep-konsep dan rumusan-rumusan teologis dogmatis tidak cukup membentuk perilaku dan pola hidup saleh, bila hanya dipahami tetapi kurang dihayati. Bila dipraktekkan dan diberlakukan di dalam kehidupan nyata, maka makna kesalehan itu akan terealisasi dan terwujud di dalamnya.

Salah satu dampak positif Pietisme adalah bangkitnya semangat memberitakan injil Kristus sebagai berita keselamatan untuk manusia berdosa. Pemberitaan injil ini dilakukan mulai pribadi ke pribadi kemudian penginjilan dilakukan kepada komunitas kecil kemudian semakin diperluas lagi ke gereja-gereja lokal sampai ke kota dan ke daerah-daerah lain. Akhirnya penginjilan ditujukan sampai kepada bangsa-bangsa di seluruh dunia. Dengan demikian tidak dapat disangkal bahwa gelombang penginjilan ke seluruh dunia yang sangat luar biasa dipicu dan dimotivasi oleh gerakan Pietisme yang menyempurnakan gerakan Reformasi Martin Luther. Penginjilan tersebut sampai ke Indonesia.

Bangsa Belanda mulai memperkenalkan ajaran Kristen Protestan untuk pertama kali di Indonesia. Mula-mula penyebaran dari ajaran itu diarahkan kepada orang di tempat perdagangan rempah-rempah kala itu, umumnya di daerah Maluku kemudian meluas ke setiap pelosok tanah air. Penyebaran agama Kristen Protestan tidak bisa ditahan-tahan dengan alasan kepentingan dagang akhirnya usaha pengajaran Kristen Protestan tetap berlangsung dan mulai terkenal saat itu, sehingga semakin banyak penduduk pribumi mulai memeluk agama Kristen Protestan.

Selain dari Belanda, ada juga pendeta dari Jerman, Amerika serta Swiss juga bekerja di Indonesia. Nama-nama gereja yang mulai didirikan yang namanya disesuaikan seperti Gereja Jawa, Gereja Kalimantan, HKBP (Huria Kristen Batak Protestan). Kedatangan para misionaris (zendeling) ke Tanah Batak sangat beragam denominasi, serta beragam motivasi. Pada umumnya mereka tidak diutus Gereja dengan denominasi tertentu. Tidak pula oleh suatu janji dan pengharapan dari siapapun, kecuali rasa keterpanggilan untuk memenuhi panggilan Kristus dalam melaksanakan firman-Nya sebagai utusan Kristus kepada bangsa-bangsa yang belum percaya kepada-Nya. Motivasi pribadi itu sangat kuat, sehingga bila kemudian ada lembaga yang mengutus, atau ada Gereja tertentu yang mendukung, hal tersebut adalah faktor tambahan. Panggilan Tuhan yang diterima secara pribadi itulah alasan pokok bagi mereka untuk bersedia diutus ke berbagai bangsa di dunia ini.

Awal masuknya Agama Kristen ke Tanah Batak pada tahun 1824 hingga perkembangannya yang baru terlihat pada tahun 1861. Sepuluh tahun kemudian (1871) sudah ada 1.250 orang Batak yang memeluk Kristen Protestan. Perkembangan ini terjadi setelah Zending Rheimsche Missions Geclechaf (RMG) dari Jerman mengutus para misionaris khusus ke Tanah Batak terutama I.L. Nommensen. Berkat kegigihan dan kesabaran zendeling dalam menghadapi suku Batak yang keras dan tertutup. Zendeling 
hidup bersama suku Batak dan berpengaruh baik dalam bidang pendidikan, kesehatan dan sosial budaya.

Setiap misionaris yang datang ke suatu daerah selalu terlebih dahulu mencari dan menemukan seorang tokoh masyarakat setempat, agar dapat menjadi pemandu dan pendukung atas tugas pekabaran Injil yang akan dilaksanakan. Salah satu kebijakan I. L. Nommensen adalah melakukan pendekatan terhadap tokoh dan para raja setempat sebelum memulai misinya. Ia terlebih dahulu menjumpai, berkenalan, dan akhirnya menjalin persahabatan dengan orang-orang yang dipandang berpengaruh di daerah yang ditujunya.

Kemudian ia menjalin kerja sama dan berupaya untuk saling mendukung dan saling membantu dengan pemimpin-pemimpin lokal yang diyakininya sebagai pemimpin formal dan kharismatik di daerah setempat. Sebelum melaksanakan tugas dan maksud kedatangannya, Nommensen selalu terlebih dahulu berupaya membangun relasi akrab, bersahabat, dan membangun hubungan harmonis dengan para pemimpin formal dan informal tersebut, yang diyakininya memiliki wibawa dan kharisma kepemimpinan terhadap masyarakat setempat.

I.L. Nommensen menjumpai seseorang yang bernama Raja Amandari Sabungan Lumbantobing. Pertemuan mereka diawali dari suatu peristiwa, saat istri Amandari boru Hutagalung jatuh sakit. Raja Amandari putus asa, karena menurut keadaan penyakit istrinya, tidak ada harapan untuk hidup. Pada pertemuan dan perkenalan pertama dengan Nommensen, Raja Amandari mengutarakan kegelisahannya itu. Atas kesedihan Nommensen, Raja Amandari membawa Nommensen ke rumahnya. Nommensen berdoa dan memberikan obat seperlunya, kemudian muzijat itu datang. Pada akhirnya istri Raja Amandari pun sembuh dari penyakitnya (Lumbantobing, 2018: 33).

Selanjutnya, Gereja yang pertama kali didirikan oleh Nommensen di Tanah Batak adalah Gereja Dame yang terdapat di wilayah Silindung (Tarutung). Penyebaran agama Kristen Protestan oleh I.L. Nommensen bukan hanya di Silindung seperti Sipirok, Samosir, Simalungun. Tahun kelahiran HKBP 7 Oktober 1861 adalah hasil keputusan berdasarkan kesepakatan dan keyakinan terhadap kuasa Roh Kudus pada peristiwa rapat Gereja yang menetapkan strategi pelayanan yang akan dilaksanakan oleh para misionaris.

Berdasarkan peristiwa tersebut (7 Oktober 1861) ditetapkan hari lahirnya HKBP. Gereja Kristen Batak sebelum nama HKBP nama yang diberikan adalah Huria Batak kemudian berubah menjadi Huria Kristen na di Tano Batak. Lalu berubah lagi menjadi Huria Kristen na di Tano Batak Sumatra. Lalu nama HKBP sendiri baru ada pada tahun 1932 resmi berdiri sebagai lembaga gereja yang terorganisir dengan nama HKBP setelah Belanda mengakuinya sebagai gereja yang berbadan hukum, sebagaimana diberitakan dalam Indische Staatblad 1932, no. 36o. Alasan pokok bagi mereka adalah, karena baru setelah keluar surat keputusan pemerintah kolonial Belanda itulah nama Huria Kristen Batak Protestan (HKBP) menjadi nama resmi. Sebelum nama itu disandang, beragam dan bermacam-macam nama yang dipakai (Arsip Almanak HKBP). 
Keadaan gereja-gereja Batak sebelum Perang Dunia II masih dipimpin oleh misionaris-misionaris dari Jerman. Namun, setelah Perang Dunia II meletus yaitu antara pihak sekutu (Amerika, Inggris, Belanda) yang berperang melawan Jerman di bawah pimpinan Adolf Hitler. Dalam perang tersebut dimenangkan oleh tentara sekutu. Akhirnya Jerman takluk kepada kekuasaan negara Sekutu. Kekalahan Jerman itu berdampak kepada HKBP. Pada waktu itu, pemimpin struktural dan pelayan misionaris di HKBP dominan berada di tangan para misionaris Jerman yang diutus RMG. Akibatnya para misionaris Jerman dibuang dan dipenjarakan. Ada yang dikirim ke negara-negara Asia lainnya berada di bawah kekuasaan Sekutu, seperti India, China, dan lain-lain. Akan tetapi ada juga yang dipenjarakan di dalam negeri, seperti di Tangsi Militer di Tarutung.

Melihat peristiwa tersebut atas dukungan dan semangat kemandirian HKBP dari kalangan jemaat, yang dipelopori para Pendeta Batak tersebut dilaksanakan Sinode Godang Istimewa HKBP. Setelah mendapat dukungan dari penguasa kolonial Belanda pada waktu itu. Sinode itu digelar pada tanggal 10-11 Juli 1940 di Seminari Sipoholon, Tarutung, dengan agenda tunggal: Pemilihan Ephorus HKBP. Hasil Sinode Godang tersebut terpilihlah sebagai Ephorus (Pucuk Pimpinan) HKBP Pdt. Kasianus Sirait (Ephorus HKBP yang pertama). Mulai saat itulah HKBP Manjungjung Baringin na (mandiri) (Lumbantobing, 2018: 75).

Pekabaran Injil di HKBP sudah dilakukan semenjak dini HKBP telah memiliki badan zending seperti Batak Zending atau Batak Nias Zending. Beberapa Pendeta telah diutus sebagai misionaris dan ke pulau-pulau lain yang terpencil dan penduduknya yang terbelakang serta masih dalam kegelapan. Zending tersebut adalah salah satu bagian dari jati diri HKBP. Sampai tahun 1970-an, pekabaran Injil yang dilakukan HKBP sangat sukses. Daerah pekabaran Injil terus diperluas dan berkembang, baik di dalam wilayah Batak maupun di luar wilayah Batak yang masih terbelakang seperti Kesakai di Riau, Pulau Rupat, suku Akit, bahkan sampai ke Sengoi di Malaysia. Melihat hal tersebut pada saat itu pekabaran Injil berjalan dengan lancar walaupun misionaris-misionaris Jerman yang pertama sekali membawa Injil ke Tanah Batak dibuang oleh Belanda bahkan dipenjarakan.

Realitas keadaan pelayanan zending ini menuntut perlunya pengembalian jati diri HKBP di bidang zending. HKBP harus kembali bangkit setelah pernah mengalami kegagalan karena kurangnya persiapan perencanaan, dan tahapan program yang matang dalam melayani pemberitaan Injil. Salah satu indikator Gereja yang hidup adalah upaya Pekabaran Injil (penyebaran agama Kristen Protestan) yang dilakukannya baik ke dalam dirinya maupun keluar yaitu kepada orang-orang yang belum mengenal Yesus Kristus melalui berbagai bidang cara untuk melakukannya di dalam kehidupan Gereja.

\section{METODE DAN FOKUS PENELITIAN}

Metode yang digunakan dalam penelitian ini adalah sejarah. Metode sejarah merupakan seperangkat langah-langkah yang digunakan untuk melakukan penulisan sejarah. Sebagaimana yang dijelaskan oleh Kuntowijoyo bahwa dalam melakukan penelitian sejarah ada lima tahapan yang harus dilewati yaitu: (1) pemilihan topik, (2) heuristik atau pengumpulan sumber, (3) verifikasi atau kritik sumber, (4) interpretasi atau 
pemafsiran, dan (5) penulisan (Kuntowijoyo, 1994: 89). Data-data yang dikumpulkan dalam penelitian ini adalah melalui: (1) observasi, (2) wawancara, (3) studi dokumen dan (4) studi pustaka.

\section{KERANGKA TEORETIK DAN KONSEPTUAL}

\section{Letak Geografis Desa Rura Tanjung}

Desa Rura Tanjung merupakan salah satu desa yang terdapat di Kecamatan Pakkat Kabupaten Humbang Hasundutan. Luas wilayahnya diperkirakan 1.50o hektar yang merupakan daerah pertanian persawahan, perkebunan, dan tanaman palawija. Jarak Desa Rura Tanjung dengan ibu kota Kecamatan yaitu Pakkat \pm 9 km dan jaraknya dengan ibu kota Kabupaten yaitu Dolok Sanggul $\pm 60 \mathrm{~km}$. Desa Rura Tanjung merupakan daerah lembah yaitu lembah (Rura) Tanjung yang dikelilingi daerah pegunungan. Daerah tersebut dialiri sungai (Aek Godang) Sisira. Sungai Sisira memiliki dua air terjun (sampuran) yaitu air terjun Sampuran Dame dan air terjun Namosarangan. Letak Desa Rura Tanjung sangat strategis. Adapun batas-batas wilayahnya sebagai berikut: sebelah utara adalah Desa Aekriman; sebelah selatan adalah desa Aek Sopang; sebelah barat adalah Desa Aekriman; sebelah timur adalah Desa Sibongkare.

\section{Pola Kekuasaan Desa Rura Tanjung}

Desa Rura Tanjung yang terdiri dari 4 dusun: Huta Ambasang, Sihorbo, Sigalapang, dan Kode Ijuk. Di sana masih berlaku pola kekuasaan tradisional walaupun sudah berbentuk sistem pemerintahan desa yang dikenal sekarang. Di setiap dusun yang dipimpin oleh raja masing-masing. Raja-raja dari setiap dusun terjadi hubungan yang harmonis bersama penduduknya walaupun ada perbedaan-perbedaan agama, pendidikan. Marga dan tempat tinggal demi untuk kemajuan dan kemakmuran Desa Rura Tanjung.

Sistem pemerintahan kerajaan di empat dusun adalah secara turun temurun. Raja di empat dusun adalah Marga Manalu dan yang dapat menjadi raja adalah putra raja yang dilahirkan oleh permaisuri (istri raja) yang disebut paniaran raja. Jika paniaran raja idak melahirkan putra mahkota, maka yang menggantikannya adalah putra dari saudara raja. Tanah tidak dikaitkan dengan klan (marga) tertentu tetapi milik bersama komunitas, karena itulah hampir di setiap dusun atau desa terdapat beberapa marga yang secara bersamaan mempunyai ikatan dengan tempat kehidupan mereka. Di antara marga-marga yang ada disetiap dusun didominasi oleh marga Manalu. Itulah sebabnya yang diangkat sebagai raja adalah marga Manalu.

Susunan pemerintahan kepala desa baru dimulai setelah Indonesia merdeka. Calon kepala desa adalah semua marga yang bersedia dicalonkan dan dipilih melalui pemilihan kepala desa yang setiap lima tahun sekali secara demokrasi. Kepala desa menjadi pemerintah desa dari keempat dusun yaitu dusun Huta Ambasang, Sihorbo, Sigalapang, dan Kode Ijuk. 


\section{Sistem Kepercayaan Masyarakat Desa Rura Tanjung}

Sebelum agama Kristen Protestan masuk ke Desa Rura Tanjung masyarakat memeluk kepercayaan animisme dan Sipele Begu yang percaya kepada roh-roh nenek moyang dan dinamisme yang menganggap bahwa benda-benda mati memiliki kekuatan yang dapat memberi pertolongan kepada manusia pada saat dibutuhkan. Misalnya seperti barang-barang peninggalan leluhur atau nenek moyang seperti pedang (podang). Maka setiap barang peninggalan tersebut harus dirawat atau dilestarikan. Kalau tidak akan dapat mendatangkan amarah/bencana bagi manusia. Sebagai medium kegiatan keagamaan/kepercayaan Sipele Begu adalah dukun (datu). Para dukun memiliki indra keenam yang dipercayai mampu meramalkan apa yang akan terjadi, mengobati, membuat penyakit, dan lain-lain. Datu dianggap memiliki kemampuan khusus, sanggup menghubungi perkasa dalam perang yang menyebabkan mereka menjadi orang sakti dalam anggapan masyarakatnya. Binatang-binatang, tanamantanaman, air terjun, atau batu, dipercaya mempunyai kekuatan gaib. Kekuatan tersebut dapat berada di mana saja sehingga dapat digunakan demi kepentingan masyarakat sendiri dengan memakai mantera atau tabas. Pemakaian tabas bukan sembarangan jika keliru dapat mendatangkan bencana bagi pemakainya atau keluarganya.

Tumbuhnya kepercayaan demikian karena banyaknya gejala alam yang tidak dapat dipecahkan oleh manusia dengan akal, gejala alam yang tidak terpecahkan itu diharapkan dapat dipecahkan melalui magic. Namun, ketika kekuatan magic pun tidak sanggup memecahkannya maka masyarakat mempercayai bahwa alam ini didiami oleh makhluk halus yang lebih berkuasa dari padanya. Kekuatan tersebut merupakan kekuatan dewa-dewa yang baik, yang jahat dan parah roh jahat, roh baik yang kesemuanya mempunyai kekuatan sakti dan dapat menyebabkan bencana jika tidak diantisipasi permintaannya. Masyarakat Rura Tanjung mempunyai konsepsi bahwa alam ini bersifat segala isinya diciptakan oleh Debata (Tuhan). Mereka membagi alam atas tiga bagian yaitu:

1) Dunia paling atas disebut banua ginjang (surge)

2) Dunia bagian tengah disebut banua tonga (tempat manusia/jolma)

3) Dunia paling bawah disebut banua pudi (tempat tinggal para hantu dan setan [sibolis] yang diperintah oleh Raja Padoha).

Dewa-dewa diyakini berperilaku hidup sebagaimana layaknya manusia yang mempunyai istri, anak, kerabat, maupun binatang peliharaanya, bermain-main, bahkan bertempur. Masyarakat Rura Tanjung memiliki kalender (ari-ari) di mana terdapat pembagian waktu yaitu satu hari terdiri dari 24 jam dan setiap tahun terdiri dari 12 bulan. Berdasarkan kalender Batak (ari-ari ni halak Batak) dapat ditentukan hari-hari baik untuk melaksanakan aktivitas-aktivitas tertentu, misalnya untuk pembangunan rumah, mengadakan perang, melangsungkan perkawinan, menanam padi dan lain-lain. Selain itu dapat juga diketahui hari-hari yang dianggap netral atau yang mengandung kuasa kesucian dan sakral. Masyarakat Rura Tanjung mempunyai falsafah yang berbunyi "martondi (roh) do na mangolu”, "marbegu (hantu) do namate"artinya manusia yang hidup mempunyai roh sementara apabila ia mati tondi (roh) tadi berubah jadi begu (semacam hantu). 
Tondi dan begu mempunyai sifat yang sangat berbeda, tondi tidak pernah mengganggu mahkluk lain, sementara begu selalu mengganggu manusia sehingga sengsara. Tondi dianggap menentukan keberuntungan dan kebahagiaan manusia pemiliknya. Tondi dapat saja meninggalkan tubuh karena adanya ketidakserasian antara tondi dan tubuh untuk. Untuk menyembuhkan agar tondi kembali ke dalam tubuh maka diadakan upacara marpangir (berpangir), mangathon sipanganon naniura ni roha (memakan makanan yang diinginkan), manjou tondi (memanggil roh) dan sebagainya.

Kemarahan tondi kepada tubuh bukan disebabkan oleh perbuatan-perbuatan yang jahat atau melanggar adat oleh yang bersangkutan, tetapi terutama oleh ketidakacuhan yang bersangkutan terhadap keinginan tondi. Tondi dapat menuntun seseorang sehingga melaksanakan perbuatan yang tercela misalnya membunuh, mencuri, dan sebagainya tanpa mengganggu keseimbangan antara tubuh dan tondi. Untuk menghindari gangguan dari begu dalam sistem kepercayaan masyarakat Rura Tanjung tradisional dilakukan acara mambahen. Pagar (membuat penangkal) dibuat berdasarkan petunjuk dan datu. Sistem kepercayaan yang telah diuraikan di atas sampai saat ini masih dipercayai dan dilaksanakan sebagian kecil masyarakat Rura Ttanjung walaupun sudah menganut agama Kristen Protestan, Katolik maupun Islam.

\section{HASIL DAN PEMBAHASAN}

\section{Sejarah Berdirinya HKBP Sihorbo Tanjung}

Masuknya agama Kristen Protestan ke Desa Rura Tanjung tidak terlepas dari peran zending HKBP seperti Batak Zending. Beberapa Pendeta atau zendeling yang diutus ke daerah-daerah, salah satunya Desa Rura Tanjung. Zending Pekabaran Injil adalah salah satu bagian dari HKBP. Sebelum Pekabaran Injil (Penyebaran Agama Kristen Protestan) masuk ke Rura Tanjung, penduduknya sebagian sudah menganut Islam. Hal ini dipengaruhi dari Islam yang dominan di Barus kebetulan berdekatan dengan Pakkat. Islam dibawa oleh para pedagang yang datang ke wilayah Pakkat. Sebagian lagi penduduk Rura Tanjung masih menganut kepercayaan nenek moyang.

Gr Ogus Hutagalung dari Batak Zending adalah yang pertama sekali diutus oleh HKBP sebagai zendeling ke wilayah Pakkat, termasuk ke Rura Tanjung. Ia dikenal sebagai pendiri Gereja HKBP yang pertama di Rura Tanjung. Gr Ogus Hutagalung dari Tarutung datang ke wilayah Rura Tanjung tahun 1920. Kedatangannya disambut oleh raja-raja di Rura Tanjung dan masyarakatnya, walaupun pada awalnya ada kendala dalam menyebarkan Injil tersebut terutama karena masih kuatnya kepercayaan nenek moyang. Walaupun demikian, ia kemudian berhasil menjalankan misinya.

Strategi yang dilakukan Gr Ogus Hutagalung dalam menyebarkan agama Kristen Protestan di Rura Tanjung dengan cara berkhotbah tentang pencipataan Allah akan dunia, permulaan dosa dan keselamatan dengan masuknya Injil (Barita Nauli) di desa tersebut, Gr Ogus Hutagalung juga menerapkan strategi dalam bentuk pelayanan Tritugas panggilan gereja yaitu Bersekutu, Bersaksi, dan Diakonia (Lumbantobing, 2018: 425). Oleh karna itu dalam pelayanan Ogus Hutagalung selalu berkhotbah mendirikan gereja, mengadakan kebaktian-kebaktian (pertangiangan-partangiangan) baik di gereja maupun di rumah-rumah penduduk. 
Gr Ogus Hutagalung dalam mendirikan gedung gereja yang pertama sebagai wadah kebaktian setiap hari Minggu ataupun di luar hari Minggu selalu berusaha mendekati raja-raja Rura Tanjung beserta masyarakat. Ia disambut dengan hati sukarela oleh raja-raja Rura Tanjung beserta masyarakatnya, terutama yang sudah menerima kehadiran agama Kristen Protestan memberikan lahan/tanah untuk tempat berdirinya gereja dan rumah Gr Ogus Hutagalung. Mulai saat itu masyarakat Rura Tanjung beserta raja-raja sebagian besar sudah menerima Injil.

Seperti yang dikemukakan oleh Manalu yang merupakan Sintua (pelayan di gereja) menuturkan bahwa "Jemaat dan penatua HKBP Sihorbo Tanjung hingga saat ini tidak dapat melupakan jasa dari Ogus Hutagalung. Demikian juga keturunannya baik yang di perantauan maupun yang tinggal di daerah tersebut selalu memberikan perhatian yang besar terhadap kemajuan Gereja HKBP Sihorbo Tanjung dengan cara memberi bantuan moril dan materil terutama untuk menghargai jasa Gr Ogus Hutagalung khusus di Rura Tanjung" (wawancara pada tanggal 11 Agustus 2019).

Strategi yang lain yang dilakukan Gr Ogus Hutagalung dalam menyebarkan Injil di desa Rura Tanjung juga membawa kemajuan di bidang pertanian dengan cara memanfaatkan lokasi gereja yang diberikan oleh masyarakat beserta raja untuk lahanlahan pertanian bekerjasama dengan masyarakat misalnya salak, petai, dan durian. Hasil tanaman tersebut dibagi-bagikan kepada jemaat atupun masyarakat yang membutuhkan. Begitu juga di bidang peternakan ikan dengan cara memberikan pelatihan cara budidaya ikan demi untuk kemajuan ekonomi jemaat ataupun masyarakat Rura Tanjung.

Setelah Gr Ogus Hutagalung meninggal dunia, usaha penginjilan terus dan semakin berkembang yang dilanjutkan oleh Penatua yang sudah mendapatkan baptisan dari Gr Ogus Hutagalung. Terbukti usaha penginjilan Gr Ogus Hutagalung yang semakin berkembang dan mengalami kemajuan hingga saat ini sejalan dengan perkembangan zaman dan tidak melanggar nilai-nilai gerejawi. Berkat peran jemaat dan penatua HKBP Sihorbo Tanjung bekerjasama dengan keturunan Gr Ogus Hutagalung di dalam membangun dan mengembangkan HKBP Sihorbo Tanjung. Usaha penginjilan Gr Ogus Hutagalung sampai saat ini terbukti mengalami kemajuan.

Sejak misionaris RMG yang datang dari Silindung (Tarutung) berhasil menyebarkan agama Kristen Protestan di Rura Tanjung tahun 1920 semakin lama semakin berkembang hingga pada tahun 2018. Berdasarkan pengamatan/survey dari peneliti bahwa pemimpin jemaat beserta Sintua bekerja sama dengan anggota jemaat berperan aktif didalam menyebarkan agama Kristen Protestan. Adapun peranan tersebut dilakukan baik secara fisik maupun non fisik.

Peranan secara fisik yaitu dengan melakukan pembangunan gereja. Sejarah pertumbuhan dan perkembangan HKBP sejak awal dimulai dengan konsep pargodungan sebuah sebutan untuk menunjuk kompleks gereja. Para misionaris mendirikan gereja dengan konsep pargodungan pada sebidang tanah yang luas, misalnya 2 atau 3 hektar, bahkan lebih. Di atas lahan pargodungan itu didirikanlah sebuah bangunan gereja, sekolah, poliklinik dan rumah para pelayan. 
Pada bagian tertentu dari lahan tersebut dimanfaatkan juga sebagai lahan pertanian, berbagai tumbuhan ditanami yang berfungsi sebagai apotek hidup. Realitas tersebut dapat ditemukan di gereja yang ada di bona pasogit, tanah leluhur orang batak. Dengan demikian, pargodungan berfungsi sebagai pusat pelayanan menyeluruh baik jasmani maupun rohani.

Gagasan membangun gereja dengan konsep pargodungan merupakan realitas konkrit untuk memperoleh hamajuon (kemajuan) masyarakat Batak Hamajuan tersebut melalui tiga pilar yaitu pemberitaan injil, pendidikan masyarakat dan kesehatan jasmani. Gereja menjadi pelopor pemberitaan firman Tuhan, pelopor pendidikan dan kesehatan masyarakat. Hingga saat ini masih ditemukan lahan luas bekas pargodungan tempo dulu, fungsi pargodungan itu sama sekali tidak ditemukan lagi.

Namun, pada gereja-gereja HKBP yang berada di daerah perkotaan maupun di luar bona pasogit (istilah untuk wilayah sekitar Danau Toba yang berarti surga/taman yang indah), fungsi pargodungan tersebut tidak ditemukan lagi. Hampir semua gereja HKBP yang ada sekarang, baik di bona pasogit, di daerah perantauan, maupun di perkotaan dibangun, pada umumnya dibangun hanya di lahan yang sempit. Tidak punya ruang parkir atau lahan pertanian yang cukup bahkan tidak mempunyai lahan membangun rumah pelayannya. Justru yang berkembang akhir-akhir ini adalah pembangunan sopo (tempat hajatan/melaksanakan kegiatan pesta, yang dibangun di kompleks gedung gereja tersebut. Pembangunan sopo ini memang mempunyai nilai ekonomi dan sosial tetapi karena begitu dekat dan rapat dengan bangunan gereja dan rumah pelayan. Dengan melihat kenyataan pergeseran jati diri tersebut, maka tepatlah waktunya kini untuk mengembangkan jati diri HKBP di bidang pargodungan.

Salah satu kekuatan dalam tubuh HKBP adalah realitas persekutuannya yang berfungsi sebagai spiritual (penyebaran injil) dan persekutuan sosial budaya. Realitas itu sudah tercipta sejak awal berdirinya Gereja Batak, yang dirumuskan sebagai wadah orang Kristen Batak. Dalam tata gereja 1930 yang kemudian direvisi tahun 1940 dirumuskan HKBP adalah persekutuan seluruh Kristen Batak dan mempunyai tujuan mempersatukan seluruh orang Batak dalam satu iman. Rumusan ini mencita-citakan bahwa HKBP adalah gereja orang Batak sebagai tempat bersekutu, baik persekutuan spiritual melalui ibadah, maupun persekutuan sosial budaya atau kultural (Lumbantobing, 2018: 344).

Di Rura Tanjung sejak kedatangan Gr Ogus Hutagalung, tahun 1958. Setelah injil tersebut diterima oleh raja-raja desa Rura Tanjung beserta masyarakat terutama yang masih memiliki kepercayaan duniawi seperti sipelebegu maka dibangunlah gereja. Walaupun bangunan gereja masih sangat sederhana sejalan dengan budaya masyarakat yang masih sangat sederhana dan kemampuan ekonomi yang masih sangat rendah. Tetapi walaupun demikian dengan semangat misionaris menyerbarkan Injil. Gereja tersebut dapat dibangun sebagai tempat persekutuan orang-orang di Rura Tanjung yang sudah percaya kepada Kristus baik persekutuan spiritual dan persekutuan sosial budaya.

Pembangunan gereja sejalan dengan perkembangan zaman dan sosial budaya dan ekonomi jemaat Kristen Protestan di desa tersebut bekerjasama dengan pemimpin 
dan pelayan gereja. Pembangunan gereja semakin berkembang dan mengalami kemajuan. Walaupun pembangunan gereja melewati proses atau tahapan-tahapan yang dimulai dari yang paling sederhana.

Tahapan-tahapan pembangunan gereja di Desa Rura Tanjung yaitu:

1) Bangunan gereja (1920-1959). Beratap rumbia, berdinding bambu dan berkolong, berukuran $5 \mathrm{~m} \times 10 \mathrm{~m}$.

2) Bangunan gereja (1959-2006). Beratap seng dan semi permanen, berukuran $7 \mathrm{~m}$ $\mathrm{X} 12 \mathrm{~m}$.

3) Bangunan gereja (2006-Sekarang). Permanen, berukuran $9 \mathrm{~m} \times 24 \mathrm{~m}$.

Dengan berdirinya Gereja HKBP dalam kurun waktu hampir 1 abad, realitas tersebut merpermudah pelaksanaan pelayanan gereja. Perpaduan realitas persekutuan spiritual misalnya beribadah dan kultural dalam dari HKBP merupakan ciri khasnya, yang memperkuat identitasnya sebagai wadah tempat bertemu sesama orang Kristen sekaligus sesama orang Batak. Sebab kemanapun orang Batak Kristen pergi, mereka mempunyai cita-cita dan harapan yang harus diwujudkan yaitu HKBP. Melalui pembangunan Gereja HKBP agama Kristen Protestan semakin berkembang di Rura Tanjung. Terbukti dari kurun waktu jemaat HKBP Sihorbo Tanjung semakin bertambah dan semakin semangat untuk mengikuti ibadah setiap hari minggu bahkan hari-hari tertentu di gereja tersebut.

\section{Aktivitas di HKBP Sihorbo Tanjung}

Salah satu jati diri HKBP adalah gereja yang hidup dengan pelayanan Diakoni (ulaon parasinirohaon) bersama dengan pekabaran Injil, keluar dan ke dalam jemaat, para misionaris sekaligus telah melaksanakan pelayanan Diakoni terhadap yang berpenyakit kusta di Huta Salem, Laguboti; orang buta dan cacat fisik di Hephata, Laguboti; selanjutnya dikembangkan pelayanan terhadap anak yatim piatu di Elims, Pematangsiantar (Lumbantobing, 2018: 439).

Injil yang diberitakan tidak hanya dalam berita kabar baik, tetapi sekaligus tindakan penyembuhan terhadap penyakit dan pemulihan status sosial secara konkrit. Pekabar Injil tidak hanya dilakukan melalui khotbah dan hanya kepada mereka yang hadir dalam ibadah gereja, tetapi juga terhadap mereka yang menderita, yang terimajinalisasi karena ketimpangan hidup sosial, atau karena penyakit yang dideritanya. Itu berarti gereja harus peka terhadap penderitaan yang dialami setiap manusia dan mau mendengar jeritan orang yang membutuhkan pertolongan. Sebab, pada hakikatnya, gereja hidup bukan untuk kebutuhan banyak orang (Lumbantobing, 2018: 353).

Dengan kehadiran HKBP Sihorbo Tanjung, dalam perjalanan sejarahnya selalu mempromosikan pelayanan Diakoni sosial sebagai pelayanan terdepan dalam kehidupan masyarakat. Oleh sebab itu, berpuluh tahun lamanya jemaat memahami dan menyikapi pelayanan gereja. Warga jemaat ikut serta berpartisipasi secara konkrit dalam pelayanan ini dengan memberikan bantuan dalam bentuk ucapan struktur yang diberikan pada setiap ibadah Minggu. Dengan demikian harus diakui bahwa pelayanan 
sosial ini (pelayanan Diakoni) merupakan jati diri HKBP yang sudah dimulai sejak berdirinya HKBP sampai sekarang.

HKBP Sihorbo Tanjung ikut serta berperan melalui pendidikan. Misalnya dengan cara memfasilitasi masyarakat pada sekolah Minggu yang diselenggarakan. Acara kebaktian Minggu terlaksana dengan baik. Para pemuda juga rela memberikan perhatiannya menjadi guru pengajar kepada anak sekolah Minggu. Sekali setahun diadakan pesta parheheon (kebangunan iman) bagi sekolah minggu. Melalui pesta parheheon tersebut anak sekolah Minggu semakin mengenal firman Tuhan melalui perlombaan baca Alkitab, cerdas cermat Alkitab.

Kegiatan para pemuda (naposo bulung) seperti melalui koor untuk mengisi acara kebaktian siang yang dimulai pukul 10.00-11.30 WIB. Setiap hari minggu dalam kebaktian siang di Gereja Sihorbo Tanjung, rutin dilaksanakan melalui acara koor tersebut para pemuda mendapatkan pendidikan tentang firman Tuhan. Para pemuda yang ikut berpartisipasi dalam kegiatan tersebut setiap hari malam minggu mengikuti latihan koor. Pemuda semakin terdidik dan semakin memahami firman Tuhan sebagai modal kehidupannya terutama pada masa depan sebagai generasi penerus terutama generasi gerejawi.

Para wanita (ina) disebut juga Parari Kamis karena setiap hari kamis mereka berkumpul untuk mengadakan latihan koor. Dalam latihan tersebut mereka membahas Alkitab, berdoa, dan aturan-aturan gerejawi, serta nyanyian-nyanyian rohani. Setiap hari Minggu dalam kebaktian Minggu siang yang masuk pukul 10.00-11.30 WIB, seksi wanita parari kamis mengisi acara Minggu tersebut.

Kelompok bapak (punguan ama) juga turut berpartisipasi dalam mengisi acara minggu setiap kebaktian siang yang dimulai pukul 10.00-11.30 WIB. Melalui kegiatan koor oleh punguan ama akan semakin memperkuat keimanan dari para bapak yang ikut terlibat dalam kegiatan tersebut. Termasuk juga pembacaan Alkitab, berdoa apabila kelompok bapak melaksanakan latihan koor yang dilakukan setiap malam hari Jumat.

Kebaktian Minggu siang dimulai pukul 10.00-10.30 WIB. Melalui kebaktian tersebut yang rutin dilaksanakan, para jemaat yang rajin ke gereja mendengarkan firman Tuhan yang dipandu oleh pemimpin gereja atau pelayan gereja akan semakin menggugah kepercayaan mereka akan firman Tuhan. Dengan demikian melalui khotbah tersebut para jemaat semakin terdidik akan firman Tuhan.

Baptisan Kudus setiap tahun selalu dilaksanakan merupakan aturan HKBP. Sebelum mendapat baptis berarti belum ada pengakuan bahwa seseorang menjadi pengikut Kristus. Biasanya Baptisan Kudus tersebut dilaksanakan pada bulan Desember. Batisan setiap tahun selalu dilaksanakan terhadap anak-anak yang lahir maupun yang datang pindah ke daerah tersebut. Melalui Baptisan Kudus tersebut para orang tua dari anak tersebut semakin mengenal firman Tuhan.

Marguru Malua merupakan aturan dalam HKBP sebelum lepas sidih. Marguru Malua diutamakan bagi anak antara umur 14-15 tahun. Selama marguru malua diberikan pelajaran khusus yang waktunya satu tahun untuk mendalami Alkitab. Marguru Malua salah satu syarat untuk lepas sidih. Tujuannya adalah untuk mempersiapkan si anak dan 
segi pengetahuan akan Injil maupun akan kematangan iman mereka sebagai iman Kristen Protestan. Setelah anak sudah mapan diberikan hak lepas sidih. Lepas sidih menurut iman Kristen Protestan adalah bahwa si anak sudah berhak turut serta dalam mengikuti perjamuan kudus untuk pengahapusan dosa. Melalui Merguru Malua si anak semakin memahami makna dari pada Injil dan nantinya iman/kepercayaan dari si anak semakin matang.

Melalui pesta sekolah Minggu yang pada umumnya dilaksanakan sekali dalam setahun. Tujuan kegiatan tersebut paling utama untuk membangkitkan iman dari anak sekolah Minggu melalui kegiatan-kegiatan dalam memeriahkan pesta parheheon (kebangkitan iman) sekolah minggu dapat semakin membangun/memperkuat keimanannya kepada Tuhan melalui Yesus Kristus, seperti Lomba Baca Alkitab, Cerdas Cermat Alkitab (CCA), Cerdas Cermat Buku Ende (CCBE). Melalui pesta parheheon (kebangkitan iman) sekolah Minggu sebagai pondasi/dasar iman semakin kuat. Dalam memeriahkan pesta parheheon tersebut dilaksanakan juga berbagai kegiatan yang dapat membangkitkan iman dari para ibu, seperti Lomba Baca Alkitab, Cerdas Cermat Alkitab (CCA), dan Cerdas Cermat Buku Ende (CCBE).

Pesta Natal adalah pesta untuk memeriahkan hari kelahiran Yesus Kristus yang puncaknya pada tanggal 25-26 Desember setiap tahun. Dalam memeriahkan pesta Natal tersebut diadakan kegiatan-kegiatan. Melalui pesta Natal sekolah minggu dilaksanakan berbagai kegiatan seperti kegiatan liturgi dengan berbagai bentuk kegiatan yang menyuarakan isi Alkitab dapat semakin memperkuat iman dari anak sekolah minggu.

Dapat dipastikan bahwa semua misionaris yang diberangkatkan zending RMG ke daerah misi (wilayah penyebaran Injil) tidak lepas dari pengaruh Pietisme yaitu penghayatan terhadap kehidupan spritualitas dengan sikap hidup praktis kesalehan sesuai dengan firman Tuhan. Dengan demikian para misionaris tersebut dipersiapkan dan diberangkatkan sesuai dengan Pietisme. Gereja-gereja muda di daerah misi menjadi pengembangan dan perluasan pengaruh Pietisme tersebut.

Warisan Pietisme yang di bawah para misionaris ke Gereja Batak tersebut termasuk HKBP Sihorbo Tanjung dapat dilihat dalam Hukum Gereja atau Siasat Gereja atau Ruhut Paminsangon, Liturgi (Agenda), Nyanyian Rohani (Buku Ende), dan lainlain. Sebagai gereja yang masih muda para misionaris terlebih dahulu mempersiapkan Ruhut Paminsangon daripada tata gereja. Sebab sebagai gereja muda masalah paling mendesak dihadapi adalah perilaku hidup orang Kristen Batak yang masih tergolong gereja muda, sehingga bila menghadapi suatu masalah sangat mudah dan cepat kembali kepada kepercayaan lama atau pengaruh zaman yang bertengtangan dengan firman Tuhan. Jadi, untuk mencegahnya, sangat dibutuhkan larangan-larangan dan aturanaturan yang memperbolehkan dan tidak memperbolehkan perbuatan praktis dalam kehidupan Kristen Batak sehari-hari. Ruhut Paminsangon tersebut di HKBP Sihorbo Tanjung tetap berlaku sesuai aturan dan peraturan HKBP.

Fungsi tanah dalam transaksi ekonomis bukanlah dalam arti bisnis seperti jual beli tanah, atau mencari untung secara ekonomi. Transaksi ekonomi yang dimaksud adalah suatu tindakan sosial dan solidaritas atas kepemilikan tanah, dari pemilik tanah terhadap orang yang hendak mengelola tanah karena ketiadaan atau kekurangan tanah yang hendak diusahakan atau dikelolanya. Tentunya tindakan tersebut berdampak 
kepada kehidupan ekonomi yang mengelolanya. Sebagai imbalannya, pemilik tanah juga memperoleh dampak ekonomis juga. Beberapa transaksi ekonomi terhadap tanah antara lain adalah Bola Pinang.

Bola Pinang adalah lahirnya niat untuk melakukan Bola Pinang atas keinginan pihak yang hendak mengerjakan tanah tersebut, jadi bukan atas keinginan pemilik tanah. Dengan demikian, Bola Pinang adalah bentuk solidaritas dan tindakan yang bersifat sosial dari pemilik tanah terhadap orang yang tidak memiliki tanah dan hendak mengelola tanahnya. Jangkau waktu Bola Pinang tersebut biasanya selalu ditentukan, misalnya satu kali atau dua kali panen.

Tanah milik HKBP Sihorbo Tanjung sebahagian diberikan untuk dikelola jemaat ataupun bukan jemaat HKBP Sihorbo Tanjung dengan cara Bola Pinang. Tanah tersebut ditanami oleh jemaat atau bukan jemaat yang hasilnya sebahagian diberikan kepada HKBP Sihorbo Tanjung dan sebahagian lagi kepada pengelola tanah tersebut sesuai dengan jumlah dan waktu yang disepakati.

\section{PENUTUP}

Berdirinya HKBP Sihorbo Tanjung tidak terlepas dari pengaruh pengembangan zending atau Pekabaran Injil ke berbagai daerah sebagi indikator panggilan gereja yang hidup seperti Zending Batak yang datang ke wilayah Rura Tanjung. HKBP Sihorbo Tanjung berdiri pada tahun 1920. Pendiri Gereja HKBP Sihorbo Tanjung adalah Gr Ogus Hutagalung yang merupakan zendeling dari Zending Batak dan sekaligus penyebar agama Kristen Protestan yang pertama di Rura Tanjung. Respons dari masyarakat beserta raja-raja Rura Tanjung menerima Injil (barita nauli) walaupun pada awalnya banyak kendala-kendala yang dihadapi Gr Ogus Hutagalung. Dengan semangat zending maka Injil tersebut dapat diterima oleh masyarakat dan raja-raja Rura Tanjung terutama yang belum menganut agama Kristen Protestan.

Peranan HKBP Sihorbo Tanjung dalam menyebarkan agama Kristen Protestan di Rura Tanjung semakin berkembang hingga sampai sekarang. Peranan tersebut, terlihat dari berbagai bidang misalnya: bidang pendidikan, bidang Diakoni (pelayanan sosial), bidang kesehatan, bidang ekonomi. Terbukti bahwa HKBP Sihorbo Tanjung semakin berkembang dan semakin maju bila dibandingkan awal terbentuknya atau berdirinya.

\section{REFERENSI}

Almanak HKBP dan Arsip Gereja HKBP Sihorbo Tanjung.

Lumbantobing, Darwin. (2018). Tumbuh Lokal Berbuah Universal. Jakarta: PT. BPK Gunung Mulia.

Kozok, Uli. (2010). Utusan Damai di Kemelut Perang (Peran Zending dalam Perang Toba). Jakarta: Yayasan Obor Indonesia.

Kuntowijoyo. 1994. Metodologi Sejarah. Yogyakarta: Tiara Wacana.

Saragih, Hisarma. (2019). Zending di Tanah Batak: Studi Tentang Konversi di Kalangan Masyarakat Simalungun, 1903-1942. Yogyakarta: Ombak. 